\title{
ANALISIS KEMAMPUAN SISWA DALAM MENYELESAIKAN SOAL UJIAN NASIONAL MATEMATIKA SMP/MTS BERDASARKAN PERSPEKTIF HIGHER ORDER THINKING SKILLS (HOTS)
}

\author{
Yohanis Ndapa Deda ${ }^{1 *}$, Astry H Ratu ${ }^{2}$, Stanislaus Amsikan ${ }^{3}$, Oktovianus Mamoh ${ }^{4}$ \\ 1,2,3,4 Prodi Pendidikan Matematika Fakultas Ilmu Pendidikan, Universitas Timor \\ Jalan Eltari km. 9, Sasi, Kefamenanu, Indonesia \\ e-mail: ${ }^{1}$ yndapadeda@unimor.ac.id;
}

corresponding author*

\begin{abstract}
Abstrak
Penelitian ini bertujuan untuk Menganalisis kemampuan matematika siswa SMP/MTs dalam menyelesaikan soal HOTS pada soal Ujian Nasional (UN) matematika. Metode penelitian yang digunakan adalah penelitian kualitatif deskriptif. Subjek penelitian adalah enam orang siswa kelas IX yang terdiri dari dua orang berkemampuan rendah, dua orang berkemampuan sedang dan dua orang berkemampuan tinggi. Pengumpulan data dalam penelitian ini menggunakan wawancara dan tes yaitu satu paket soal UN tiap tahun dari 2016-2018, kemudian divalidasi oleh ahli, terpilih tujuh butir soal yang tergolong HOTS. Soal tersebut meliputi satu butir soal dari tahun 2016, dua butir soal dari tahun 2017, dan empat butir soal dari tahun 2018. Instrumen yang digunakan adalah pedoman wawancara dan soal UN yang berkategori HOTS. Hasil penelitian menunjukkan bahwa Siswa yang berkemampuan rendah hanya mampu menyelesaikan soal HOTS level menganalisis (C4) dan mengevaluasi (C5), sedangkan siswa berkemampuan sedang ternyata memiliki kemiripan dengan siswa yang berkemampuan tinggi, yaitu mampu menyelesaikan sebagian butir soal HOTS level menganalisis (C4), mengevaluasi (C5) dan mencipta (C6). Secara umum rata-rata kemampuan siswa MTs Nurul Falah cukup bagus dalam mengerjakan soal-soal HOTS.
\end{abstract}

Kata Kunci: kemampuan matematika, ujian nasional, hots

\section{AN ANALYSIS OF JUNIOR HIGH SCHOOLS STUDENTS' ABILITY IN RESOLVING THE NATIONAL EXAM MATHEMATICS BASED ON PERSPECTIVE HIGHER ORDER THINKING SKILLS (HOTS)}

\begin{abstract}
This study aims to analyze the ability of mathematics junior high school students in resolving the mathematics HOTS in the national exam (UN). The methodology used is a descriptive qualitative study. The subject of study is six students of ninth grade consisting of two capable, two people are low capacity, and two others high-profile. Data collection in this research using interviews and test one package the exam every year from 2016-2018, then been validated by the expert, who is elected seven items of about which include an item in 2016, two items of the year 2017, and four items of the year 2018. An instrument used is an enlightenment interview and the national exam in HOTS categorize. The result showed that students low capable with only able to solve the item number-1 and number-4 wich including in HOTS level-4 and 5 , and students who are capable of being able to solve problems HOTS have similarities with students who are highly capable of being able to solve the questions number 1, 2, 3, 4, and 7 with HOTS levels 4, 5, and 6.
\end{abstract}

Keywords: mathematical ability, national exams, hots

Copyright ( 9 Authors. This is an open access article distributed under the Attribution-NonCommercialShareAlike 4.0 International (CC BY-NC-SA 4.0), which permits unrestricted use, distribution, and reproduction in any medium, provided the original work is properly cited. 


\section{Pendahuluan}

Mencerdaskan kehidupan bangsa merupakan salah satu upaya yang dapat dilakukan melalui kegiatan pendidikan. Pendidikan yang merupakan sebuah program terencana dan melibatkan komponen yang akan bekerja sama untuk mencapai tujuan yang telah diprogramkan. Upaya yang bertujuan untuk mengarahkan siswake dalam suatu proses pembelajaran, sehingga siswamampu mencapai tujuan akhir belajar yaitu manusia yang berkualitas dan mampu beradaptasi dengan perkembangan jaman.

Di era globalisasi membutuhkan sumber daya manusia yang kompetitif sehingga mampu menghadapi tuntutan perkembangan jaman yang semakin maju (Syarbaini, 2016). Kualitas sumber daya manusia suatu bangsa ditentukan oleh tingkat pendidikan bangsa tersebut, yang diwujudkan melalui program pendidikan karena pendidikan merupakan wahana untuk meningkatkan dan mengembangkan kualitas sumber daya manusia. Aktualisasi program pendidikan di sekolah, memberikan kesempatan bagi siswauntuk mengembangkan potensinya. Salah satu bidangnya adalah matematika merupakan salah satu mata pelajaran yang sangat penting karena matematika merupakan ilmu yang dapat melatih untuk berpikir kritis, sistematis, logis, dan kreatif. Matematika juga memiliki struktur dan keterkaitan yang kuat dan jelas antar konsepnya, sehingga memungkinkan siswaterampil berpikir rasional. Mengingat hal tersebut, penting untuk mempelajari matematika tidak hanya sekedar mengetahui tetapi juga berusaha untuk memahami dan bisa mengaplikasikannya dalam persoalan kehidupan nyata.

Kualitas pendidikan Indonesia belum menunjukkan capaian yang menggembirakan. Ada beberapa indikator yang menunjukkan masih tertinggalnya kualitas pendidikan di Indonesia jika dibandingkan dengan Negara-negara lain, terutama jika dilihat dari kualitas Sumber daya manusia. Menurut data Human Development Index (HDI), pada tahun 2015 nilai HDI Indonesia adalah 0,689 yang menempatkan Indonesia pada medium human Development group. Human Development Index (HDI) merupakan sebuah organisasi yang mengukur kualitas SDM tiap Negara (HDI, 2016).

Melihat kualitas SDM yang masih rendah, perbaikan dan peningkatan kualitas pendidikan terus dilakukan melalui tingkat penjaminan mutu. Pada Permendiknas No. 63 Tahun 2009 pasal 1 ayat 2 bahwa penjaminan mutu pendidikan adalah kegiatan sistemik dan terpadu oleh satuan atau program pendidikan, penyelenggara satuan atau program pendidikan, pemerintah daerah, pemerintah, dan masyarakat untuk menaikan tingkat kecerdasan kehidupan bangsa melalui pendidikan.

Banyak program yang dilakukan oleh pemerintah Indonesia untuk meningkatkan kualitas mutu pendidikan di Indonesia salah satunya adalah kegiatan evaluasi yang berupa Ujian Nasional (UN). UN merupakan tes resmi yang diadakan pemerintah yang bertujuan untuk mengukur tingkat ketercapaian standar nasional pendidikan terkait dengan pencapaian standar kompetensi lulusan siswasecara nasional. Salah satu bentuk evaluasi yang mengukur kompetensi lulusan siswa dari aspek kognitif yaitu kualitas UN selalu ditingkatkan. Peningkatan kualitas UN dengan meningkatkan derajat kesulitan soal ini berkaitan dengan peningkatan jumlah item soal yang mengukur ketrampilan berpikir tingkat tinggi (high order thinking).

Soal yang melibatkan proses berpikir tingkat tinggi cenderung kompleks dan merupakan soal yang memiliki banyak solusi atau banyak cara pengerjaan sesuai dengan pengalaman dan pengetahuan masing-masing peserta didik (Ahmad \& Sukiman, 2019). Hal ini tidak terlepas dari kemampuan siswa yang heterogen, tinggi, sedang, dan rendah. Keterampilan berpikir tingkat tinggi sangat penting karena keterampilan siswa menyelesaikan soal level HOTS dapat membantu siswa mengatasi kesulitan mengembangkan ide-ide kreatif (Heong, dkk, 2011), belajar dan mengajar menggunakan pendekatan HOTS juga bermanfaat bagi siswa dalam mengembangkan keterampilan berpikir (Wang, 2014), strategi berpikir tingkat tinggi juga membantu siswa menjadi lebih mandiri dalam proses belajar dan mengajar (Teimourtash \& Moghaddam, 2017).

Berdasarkan penelitian yang dilakukan Gais \& Afriansyah (2017) menunjukkan bahwa terdapat pengaruh kemampuan awal matematis siswa terhadap penyelesaian soal HOTS dalam segala aspek. Siswa dikategorikan mampu menyelesaikan soal-soal HOTS. Faktor-faktor yang menyebabkan siswa keliru dalam menyelesaikan soal-soal HOTS diantaranya adalah kurang teliti dalam proses mengerjakan soal, rendahnya kemampuan awal matematis peserta didik, tidak maksimalnya proses yang dilalui selama pembelajaran, kurangnya pemahaman siswa terhadap soal, ketidaklengkapan dalam membaca soal dan kurangnya perhatian dari orang tua. Hasil penelitian Qoni'ah (2017) menunjukkan bahwa banyaknya butir soal berkategori HOTS pada UN tahun 2013 sebesar (7,5\%), pada UN tahun 2014 sebesar (12,5\%) dan pada UN tahun 2015 sebesar 
(10\%). Hasil tersebut menunjukkan jumlah soal HOTS pada soal UN Matematika SMP/MTs tiap tahunnya tidak konsisten. Hal inilah yang menjadi salah satu penyebab siswa lemah dalam menyelesaikan Soal berkategori HOTS. Jumlah butir Soal HOTS yang kurang dari sepuluh (10) menyebabkan siswa lebih fokus mengerjakan soalsoal rutin untuk mencapai nilai standar kelulusan dalam menghadapi UN. Hasil UN pada mata pelajaran matematika MTs Nurul Falah masih di bawah rata-rata dan jumlah butir soal berkategori HOTS sekitar 25\% dari jumlah soal UN menjadi dasar untuk menganalisis kemampuan siswa dalam menyelesaikan Soal Un berkatogori HOTS di MTs Nurul Falah Kefamananu. Data persentase siswa MTs Nurul Falah yang mejawab benar pada saat UN tahun 2019 mata pelajaran matematika untuk materi Bilangan, Geometri dan pengukuran masih di bawah persentase Siswa pada tingkat Kabupaten Timor Tengah Utara. Persentase UN pada mata pelajaran matematika MTs tersebut juga masih di bawah persentse provinsi dan nasional.

Kebanyakan soal yang digunakan oleh sekolah di Indonesia sebagai instrumen penilaian kognitif adalah soal yang cenderung bertujuan untuk menguji lebih banyak pada aspek memori, sedangkan soal untuk melatih kemampuan berpikir tingkat tinggi siswa tidak cukup banyak tersedia (Kusuma, Rosidin, \& Suyatna, 2017). Padahal soal-soal HOTS saat ini menjadi instrumen yang tekankan seperti UN dan Ujian Tulis Berbasis Komputer (UTBK). Soal-soal HOTS juga selalu digunakan pada survey internasional seperti Programme for International Student Assessment (PISA). Untuk itu, sangat penting menganalisis dan mengembangkan soal-soal berdasarkan perspektif HOTS. Perspektif HOTS yang dimaksud mengacu pada taksonomi Bloom revisi dan penyempurnaan oleh Anderson tahun 2010. Taknomi Bloom edisi lama setelah direvisi dan sempurkan menjadi mengingat $(\mathrm{C} 1)$, memahami $(\mathrm{C} 2)$, menerapkan (C3), menganalisis (C4), mengevaluasi (C5) dan mencipta (C6) (Basuki dan Hariyanto, 2016).

\section{Metode Penelitian}

Penelitian ini merupakan penelitian kualitatif yang dilaksanakan di MTs Nurul Falah Kefamenanu pada April 2019. Subjek dalam penelitian ini adalah 6 orang siswa kelas IX MTs Nurul Falah Kefamenanuyang terdiri dari 6 orang yaitu 2 orang yang berkemampuan tinggi, 2 orang berkemampuan sedang dan 2 orang berkemampuan rendah yang dipilih dari hasil perangkingan tes yang dilakukan. Prosedur penelitian yaitu (1) mengumpulkan soal UN tahun 2016 sampai 2018 yang diambil satu paket tiap tahun; (2) memilih soal UN yang berkategori HOTS sesuai dengan Taksonomi Bloom Anderson; (3) melakukan validasi soal UN berkategori HOTS; (4) memodifikasi soal UN menjadi soal uraian; (5) melakukan uji coba soal HOTS; (6) mengolah data dan menarik kesimpulan. Instrument dalam penelitian ini yaitu soal tes dan pedoman wawancara. Teknik pengumpulan data berupa dokumen soal, tes tertulis dan wawancara.Teknik analisis data pada penelitian ini dengan reduksi data, penyajian data, dan kesimpulan. Analisis tersebut didahului dengan melakukan analisis dokumen, analisis hasil tes, dan data hasil wawancara, Menganalisis kemampuan berpikir tingkat tinggi siswa dalam menyelesaikan soal UN berkategori HOTS berdasarkan hasil tes tertulis yang didukung dengan hasil wawancara.

\section{Hasil dan Pembahasan}

\subsection{Analisis Soal UN Matematika SMP/MTs}

Tabel 1. Jumlah Soal UN Tahun 2016-2018 Berkategori HOTS dan Hasil Validasinya

\begin{tabular}{cccc}
\hline Tahun & Jumlah Soal & HOTS & Validasi \\
\hline 2016 & 40 & 5 & 1 \\
2017 & 40 & 5 & 2 \\
2018 & 40 & 7 & 4 \\
\hline Rata-rata & 40 & 5.67 & \\
Total & 120 & 17 & 7 \\
\hline
\end{tabular}

Rata - rata jumlah butir soal berkategori HOTS Tabel 1 hanya 5.67, angka ini menunjukkan bahwa pembuat soal kurang kreatif dalam mevariasi soal-soal yang berkategori HOTS sesuai taksonomi Bloom revisi Anderson. Data pada Tabel 1 juga diperoleh 17 butir soal UN berkategori HOTS. Setelah divalidasi oleh ahli, dari 17 Soal tersebut diperoleh 7 butir soal Berkategori HOTS yang valid. Soal yang telah valid sesuai kategori HOTS kemudian di modifikasi dari tipe soal pilihan ganda menjadi tipe soal uraian yang siap digunakan.

\subsection{Ujicoba Soal UN Berkategori HOTS}

Pada tanggal 16 April 2019 dilakukan tes soal HOTS di MTs Nurul Falah dengan jumlah siswa 22 orang. Kemudian dari hasil tes tersebut peneliti mengambil enam (6) orang siswa untuk dianalisis jawabannya, tabel hasil tes 6 orang siswa dan rumus persentase sebagai berikut:

$$
\frac{j u \text { mlah siswa jawab benar }}{j u \text { mlah seluruh siswa(22) }} \times 100 \%
$$


Tabel 2. Hasil Tes Enam Orang Siswa

\begin{tabular}{llllllllll}
\hline \multirow{2}{*}{ No } & \multirow{2}{*}{ Nama } & \multicolumn{1}{c}{ Nomor Soal } & \multicolumn{1}{c}{ Total } \\
& & 1 & 2 & 3 & 4 & 5 & 6 & 7 & Nilai \\
\hline 1 & MS & 0 & 0 & 0 & 12 & 0 & 0 & 11 & 23 \\
2 & AF & 16 & 6 & 11 & 12 & 7 & 0 & 0 & 52 \\
3 & NPI & 16 & 16 & 16 & 11 & 0 & 0 & 16 & 75 \\
4 & HA & 16 & 0 & 16 & 15 & 9 & 7 & 16 & 79 \\
5 & NSP & 15 & 16 & 16 & 15 & 9 & 7 & 16 & 94 \\
6 & CMDP & 16 & 16 & 16 & 16 & 9 & 7 & 16 & 96 \\
\hline
\end{tabular}

$\begin{array}{llllllll}\text { Presentase } & 83.3 & 50 & 66.7 & 50 & 0 & 0 & 66.7\end{array}$

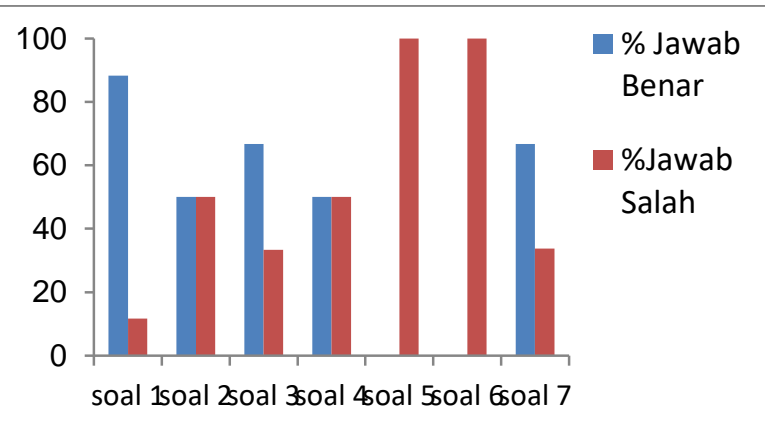

Gambar 1. Persentase Siswa Menjawab Soal HOTS

Gambar 1 dan Tabel 2 terlihat bahwa persentase soal nomor 5 dan 6 adalah nol, tidak ada siswa yang menjawab dengan benar. Siswa yang berkemampuan tinggi, sedang dan rendah tidak memahami soal yang dikerjakan. Siswa-siswa tersebut menjelaskan alasan mereka tidak mengerjakan soal nomor 5 dan 6 yang tergolong level mencipta, Setelah dikonfirmasi ternyata mereka merasa sulit karena tidak terbiasa mengerjakan soal-soal berkategori HOTS. Selama ini mereka hanya mengerjakan soal-soal rutin yang diberikan guru sesuai buku teks. Menurut Gais, dkk (2017) bahwa siswa merasa sulit dalam mengerjakan soal HOTS karena beberapa faktor seperti kemampuan awal yang rendah, kurang teliti, kurang pemahaman terhadap soal dan tidak lengkap dalam membaca soal.

Data pada Gambar 1 terlihat bahwa persentase tertinggi siswa menjawab dengan benar berada pada soal nomor 1. Menurut taksonomi Bloom soal tersebut mengukur kemampuan siswa pada bagian menciptakan atau level soalnya C6 dengan materi segi empat dan segitiga. Sedangkan persentase terendah siswa menjawab dengan benar berada pada soal nomor 5 dan 6 . Mengacu pada taksonomi bloom soal tersebut mengukur kemampuan siswa pada bagian menciptakan atau level soalnya C6 dengan materi kekongruenan dan kesebangunan. Soal nomor 1, 2, 4 menurut taksonomi bloom soal tersebut berturut-turut mengukur kemampuan siswa pada bagian menciptakan, mengevaluasi, menganalisis atau level soalnya C6, C5, dan C4 (Anderson, Lorin \& David, Krathwohl, 2010).

\subsection{Rekapitulasi Kemampuan Siswa Menyelesaikan Soal HOTS}

Hasil kemampuan siswa dalam menyelesaikan soal HOTS dapat dilihat pada tabel berikut ini.

Tabel 3. Kemampuan Siswa Menyelesaikan Soal HOTS

\begin{tabular}{lllll}
\hline No & Nama Siswa & $\begin{array}{l}\text { Kategori } \\
\text { Kemampuan } \\
\text { Matematis }\end{array}$ & $\begin{array}{l}\text { Nomor soal dijawab } \\
\text { benar }\end{array}$ & Level Soal (HOTS) \\
\hline 1 & MS & Rendah & 4 & C4 \\
2 & AF & Rendah & 1 dan 4 & C6 dan C4 \\
3 & HA & Sedang & $1,3,4$ dan 7 & C6 dan C4 \\
4 & NPI & Sedang & $1,2,3$ dan 7 & C6, C5, dan C4 \\
5 & NSP & Tinggi & $1,2,3,4$ dan 7 & C6, C5, dan C4 \\
6 & CMDP & Tinggi & $1,2,3,4$ dan 7 & C6, C5, dan C4 \\
\hline
\end{tabular}

\subsection{Deskripsi Kemampuan Matematika Berdasarkan Tingkat Kemampuan Siswa}

\section{a. Siswa Berkemampuan Matematika Rendah} (MS dan AF)

Berdasarkan hasil analisis, siswa MS dan AF yang berkemampuan matematika rendah hanya mampu menjawab 3 soal dengan benar dari 7 soal yang diberikan. Siswa MS dan AF hanya mampu menjawab benar soal nomor $\mathrm{C} 1$ dan $\mathrm{C} 4$ dengan level soalnya menganalisis dan menciptakan
(Anderson, dkk., 2010). Untuk soal nomor 2, 3,5,6, dan 7, MS dan AF tidak mampu menjawab. Ketika dikonfirmasi melalui wawancara, untuk soal nomor 4, siswa MS dan AF sudah mampu menganalisis masalah yang ada di soal dan ada beberapa langkah pengerjaan yang dilanggar tetapi melalui wawancara kembali mereka menjelaskan secara benar dan jelas. Hal ini dikarenakan siswa sudah masuk pada pembahasan soal-soal UN. Namun jumlah butir soal yang masuk kategori HOTS sangat sedikit. Akibatnya siswa yang berkemampuan rendah kesulitan menjawab soal- 
soal HOTS yang diberikan. Sebagian siswa berkemampuan rendah hanya mencapai indikator menganalisis (C4) berdasarkan Taksonomi Bloom yang direvisi (Nugroho \& Arifin, 2018).

b. Siswa Berkemampuan Matematika sedang (HA dan NPI)

Berdasarkan hasil analisis, siswa HA dan NPI yang berkemampuan matematika sedang mampu menjawab 5 soal dengan benar dari 7 soal yang diberikan. Siswa HA dan NPI hanya mampu menjawab benar soal nomor 1, 2, 3, 4, dan 7 dengan level C4, C5 dan C6 (Anderson, dkk, 2010). Untuk soal nomor 5 dan 6, HA dan NPI tidak mampu menjawab. Ketika dikonfirmasi melalui wawancara, untuk soal nomor 1, 2, 3, 4, dan 7 siswa HA dan NPI sudah mampu menciptakan, menganalisi, mengevaluasi apa yang ada dalam soal dan sudah mampu menjelaskan dengan benar sesuai rubrik penyelesaian yang telah dibuat. Pada soal nomor 2 siswa NPI menjawab dengan benar tetapi menggunakan cara yang berbeda dari rubrik yang dibuat. Hal ini dikarenakan siswa sudah masuk pada pembahasan soal-soal UN. Butir soal HOTS yang jumlahnya sangat sedikit membuat siswa berkemampuan sedang tidak bisa sepenuhnya mencapai indikator mencipta (C6) berdasarkan Taksonomi Bloom yang direvisi (Nugroho, dkk, 2018).

\section{c. Siswa Berkemampuan Matematika Tinggi (CMDP dan NSP)}

Berdasarkan hasil analisis, siswa CMDP dan NPS yang berkemampuan matematika tinggi mampu menjawab 5 soal dengan benar dari 7 soal yang diberikan. Siswa CMDP dan NPS hanya mampu menjawab benar soal nomor $1,2,3$, 4, dan 7 dengan level soalnya C4, C5, dan C6 (Anderson, dkk, 2010). Untuk soal nomor 5 dan 6, CMDP dan NPS tidak mampu menjawab. Ketika dikonfirmasi melalui wawancara, untuk soal nomor 1, 2, 3, 4, dan 7 siswa CMDP dan NPS sudah mampu menjelaskan dengan benar sesuai rubrik penyelesaian yang telah di buat. Pada soal nomor 2 siswa CMDP dan NPS menjawab dengan benar tetapi menggunakan cara yang berbeda dari rubrik yang di buat. Untuk soal nomor 5 dan 6, siswa CMDP dan NPS sudah mampu mengetahui dan menganalisis apa yang ada di soal tetapi belum sampai pada proses menciptkan atau mengkreasikan jawaban mereka. Hal ini di karenakan siswa sudah masuk pada pembahasan soal-soal UN dari tahun ke tahun dan soalnya memiliki kemiripan dengan soal tes. Akan tetapi jumlah butir soal yang masuk kategori HOTS jumlahnya sangat sedikit. Akibatnya siswa yang berkemampuan tinggi tidak bisa mencapai indikator mencipta (C6) berdasarkan Taksonomi Bloom yang direvisi (Nugroho, dkk., 2018).

Dari tujuh butir soal berkategori HOTS yang diberikan pada siswa MTs Nurul Falah Kabupaten TTU memperoleh rata-rata 69.8, ada 2 (dua) butir soal yang tidak dikerjakan karena kemampuan siswa pada tingkat menciptakan atau level soal HOTS C6 dengan materi kekongruenan dan kesebangunan masih sangat rendah. Soal nomor 5 meminta siswa menyelesaikan masalah sehari-hari yang berkaitan dengan operasi himpunan. Hal ini sejalan dangan hasil UN MTs Nurul Falah, tahun 2019 yaitu daya serap pada indikator menyelesaikan masalah operasi irisan /gabungan himpunan dengan diagram venn mencapai $44.46 \%$ masih di bawah rata-rata nasional yaitu $60.74 \%$ (Puspendik, 2019). Soal nomor 6 meminta siswa menentukan panjang sisi atau besar sudut yang belum diketahui dari dua bangun segi banyak yang sebangun. Siswa-siswa di MTs tersebut belum bisa membuat garis bantu dan belum memahami konsep kesebangunan dengan baik. Rata-rata kemampuan siswa MTs Nurul Falah cukup bagus meskipun selama ini mereka tidak terbiasa mengerjakan soalsoal HOTS

\section{Kesimpulan}

Siswa yang berkemampuan rendah hanya mampu menyelesaikan soal HOTS level menganalisis (C4) dan mengevaluasi (C5), sedangkan siswa berkemampuan sedang ternyata memiliki kemiripan dengan siswa yang berkemampuan tinggi, yaitu mampu menyelesaikan sebagian butir soal HOTS level menganalisis (C4), mengevaluasi (C5) dan mencipta (C6). Secara umum rata-rata kemampuan siswa MTs Nurul Falah cukup bagus dalam mengerjakan soal-soal HOTS.

\section{Daftar Pustaka}

Ahmad \& Sukiman, 2019. Analisis Higher Order Thinking Skills (HOTS) Pada Soal Ujian Akhir Siswa Kelas 6 Kmi Dalam Kelompok Mata Pelajaran Dirosah Islamiyah Di Pondok Modern Tazakka Batang. Jurnal Pendidikan Agama Islam, 16 (2), 137-164.

Anderson, Lorin. W \& David R. Krathwohl (Eds). 2010. Kerangka Landasan untuk Pembelajaran, Pengajaran, dan Asesmen: Revisi Taksonomi Pendidikan Bloom. Terjemahan oleh Agung Prihantoro. Yogyakarta: Pustaka Pelajar.

Basuki \& Hariyanto, 2016. Asesmen Pembelajaran. Bandung: PT Remaja Rosdakarya. 
Gais, Z \& Afriansyah, E.A. 2017. Analisis Kemampuan Siswa Dalam Menyelesaikan Soal High Order Thinking Ditinjau Dari Kemampuan Awal Matematis Siswa. Jurnal "Mosharafa", 6(2), Mei 2017. (online), https://media.neliti.com/media/publications/226 677-analisis-kemampuan-siswa-dalammenyelesa-e86fba01.pdf

HDI. 2016. Human Development for Everyone Briefing note for countries on the 2016 Human Development Report. http://www.id.undp.org/content/dam/indonesia/2 017/doc/INSIndonesia_Country\%20Explanatory \%20Note_HDR2016.pdf

Heong, YM, Yunos, J. Md., Othman, W., Hassan, R, Kiong, T.T., Mohamad, M.M. 2012. The needs analysis of learning higher order thinking skills for generating ideas. Procedia - Social and Behavioral Sciences 59 (2012): 197 - 203.

Kusuma, M. D., Rosidin, U., \& Suyatna, A. 2017. The Development of Higher Order Thinking Skill HOTS Intrument Assesment in Physics Study. IORS Journal of Research \& Method in Education , 7 (1), 26-32.
Nugroho, \& R., Arifin. 2018. HOTS, Kemampuan Berpikir Tingkat Tinggi, Konsep, Pembelajran, Penilaian dan Soal-soal. Jakarta: PT Gramedia.

Permendiknas No. 63 Tahun 2009 Tentang Sistem Penjaminan Mutu Pendidikan.

Pusat Penelitian Pendidikan (Puspendik). 2019. Laporan Hasil Ujian Nasional SMP Tahun Ajaran 2018/2019. Jakarta: Kemdikbud.

Qoni'ah, L. 2017. Analisis Soal Ujian Nasional Matematika Tingkat Smp/Mts Tahun 2013-2015 Berdasarkan Perspektif Higher Order Thinking Skill (Hots) : skripsi

Wang, S \& Wang, H. 2014. Teaching and Learning High Order Thinking. International Journal of Arts \& Sciences, 07(02):179-187.

Morteza Teimourtash \& Massood Yazdani Moghaddam. 2017. On the Plausibility of Bloom's Higher Order Thinking Strategies on Learner Autonomy: The Paradigm Shift. AsianPacific Journal of Second and Foreign Language Education, DOI 10.1186/s40862-017-0037-8.

Syarbaini, S. 2016. Kesadaran Berbangsa Dan Bernegara. http://ueu5483.weblog.esaunggul.ac.id/2016/05/ page/2/. 